\title{
DGI-INDONESIA.COM: EMPAT TAHUN UNTUK KOMUNITI INDONESIA KREATIF
}

\author{
Danu Widhyatmoko \\ Jurusan Desain Komunikasi Visual, School of Design, BINUS University \\ Jln. K.H. Syahdan No. 9, Palmerah, Jakarta Barat 11480 \\ danu@binus.edu
}

\begin{abstract}
DGI-Indonesia.com as a community site is able to answer the new needs of the virtual space. This paper will begin with the history of DGI-Indonesia.com; then the discussion about the roles undertaken by the DGI-Indonesia.com. Research method used in this paper is literature study, continued with reflective data analysis. By the end of the paper, a more comprehensive picture about DGI-Indonesia.com's activities such as a forum for self-actualization, interaction, exploration that helps sustain the development of science-based and creative professions in Indonesia.
\end{abstract}

Keywords: DGI-Indonesia.com, community sites

\begin{abstract}
ABSTRAK
DGI-Indonesia.com sebagai situs komuniti mampu menjawab kebutuhan baru atas ruang maya. Tulisan ini diawali dengan sejarah perkembangan DGI-Indonesia.com, lalu akan dibahas peran demi peran yang dijalankannya. Metode penelitian yang digunakan dalam penulisan ini adalah studi literatur yang dilanjutkan dengan analisa data reflektif. Hingga pada akhir tulisan bisa didapatkan gambaran yang lebih jelas mengenai aktivitas yang dijalankannya sebagai wadah aktualisasi diri, interaksi, eksplorasi yang turut menopang berkembangnya ilmu dan profesi berbasis kreatif di Indonesia.
\end{abstract}

Kata kunci: DGI-Indonesia.com, situs komuniti 


\section{PENDAHULUAN}

DGI-Indonesia.com sebagai situs berbasis komuniti berusaha menjawab perubahan dunia yang terus berkembang secara pesat dalam membentuk kehidupan baru di dunia maya. Selama empat tahun perjalanannya, DGI-Indonesia.com berusaha untuk memberikan ruang baru untuk aktualisasi, eksplorasi, interaksi, serta saling berbagi. Pola yang dikembangkan berupa membangun komuniti di dunia maya dengan memanfaatkan manajemen sumberdaya budaya lewat teknologi informasi komputer. Selain itu, peran sosial yang menjiwai perjalanan DGI-Indonesia.com ternyata mampu memberikan kreativitas dalam menjawab perubahan serta tantangan.

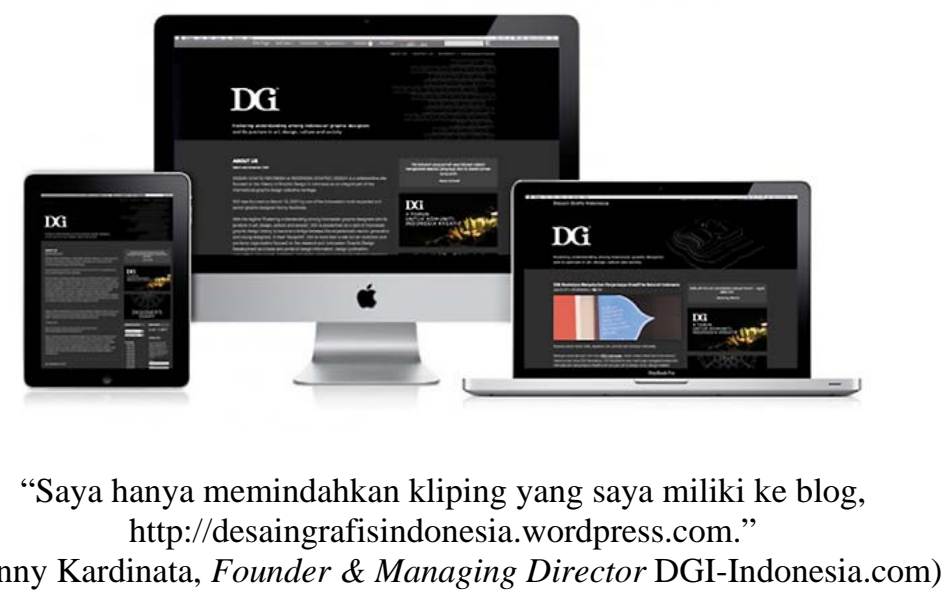

\section{METODE}

Penulisan ini disusun menggunakan pendekatan studi literatur untuk mendapatkan data-data pendukung serta mencari kerangka teori guna menguatkan hasil penulisan. Kemudian setelah datadata didapatkan maka akan dilakuakan analisa data refletif. Analisa Reflektif adalah metode analisa data yang berpedoman pada cara berfikir reflektif. Pada dasarnya metode ini adalah kombinasi yang kuat antara berfikir deduktif dan induktif atau dengan mendialogkan data teoritik dan data empirik secara bolak balik kritis (Stain, 2002).

Dengan metode analisa reflektif, penulis akan mencari makna yang terkandung dari hasil pengumpulan data yang telah dilakukan, untuk diperbandingkan antara literatur yang ada dengan keadaan ataupun fenomena yang tertangkap. Sehingga dapat diperoleh kesimpulan data yang rasional dan ilmiah.

\section{PEMBAHASAN}

\section{Perjalanan DGI-Indonesia.com}

Situs tersebut tampil dalam kesederhanaan, hitam, abu-abu dan putih. Terkelompok dalam warna akromatik yang sangat mendominasi. Identitas yang kuat segera terasa bila melihat sudut kiri atas, sebuah logogram bertutur "DGI" hadir dalam bentuk ligatur. Ligatur sendiri berarti dua huruf atau lebih yang bersatu membentuk visual/huruf baru. "Spontan. Berkarakter Indonesia, sederhana penampilannya dan dirancang sebagai logo yang tahan usia, langgeng dan bukan sekedar logo untuk 
sebuah event khusus yang sifatnya sementara,” al tersebut diungkapkan oleh Henricus Kusbiantoro, Creative Director DGI-Indonesia.com yang merancang logo tersebut. Henricus sendiri telah malang melintang di industri branding Amerika Serikat, dari Chermayeff \& Geismar, Wolff Olins, hingga Landor Associates, semua berada di New York. Logogram tersebut menyatu, menyelaras dengan kesederhanaan tampilan desain situs yang dikembangkan oleh Danu Widhyatmoko.

Namun, kesederhanaan yang tampak pada situs tersebut tetap tidak dapat menutupi kekuatan jumlah data serta informasi yang dimiliki. Sebanyak 1.872 artikel dimiliki oleh situs tersebut (Data per 2 Juli 2011), 7.000 komentar lebih turut hadir menyertai, membangun diskusi menarik di antara para pengunjung DGI-Indonesia.com. Kemudahan navigasi untuk mengakses seluruh artikel yang ada disusun dengan sejumlah pendekatan, berdasar kerangka waktu, kategorisasi, jenis media, dan termasuk tentunya memanfaatkan fasilitas mesin pencari. Kemudahan pencarian data oleh pengunjung menjadi perhatian utama dari pengembangan situs ini, mengingat jumlah data yang dimiliki oleh DGIIndonesia.com yang akan terus berkembang.

Berbicara mengenai DGI-Indonesia tidak dapat dilepaskan dari sosok seorang Hanny Kardinata, sosok senior yang sangat dihormati di ranah keilmuan maupun profesi desain grafis Indonesia. Mengawali proses dokumentasi data serta informasi desain grafis Indonesia lewat langkah yang sangat sederhana, "Saya hanya memindahkan kliping yang saya miliki ke blog http://desaingrafisindonesia.wordpress.com" --alamat awal situs DGI Indonesia. Pada awalnya kegiatan tersebut dilakukan untuk mengisi waktu di sela proses penyembuhan indra penglihatan yang dimilikinya. Kecintaan Hanny atas data, terekam jelas lewat koleksi kliping seputar desain grafis yang dimiliki. Kini, koleksi data kliping yang dimiliki tersebut secara perlahan telah berpindah seluruhnya ke dunia maya, tak lagi menjadi wilayah yang dapat dinikmati secara pribadi, namun diberikan sepenuhnya hak akses yang ada bagi siapapun yang membutuhkan. Kutipan "Dedicated to all my friends in graphic design community" yang kerap dituliskan menyertai profil dirinya tak lagi sekedar pernyataan kosong tanpa makna, justru sebaliknya, menjadi karya serta aksi nyata yang mengisi kesehariannya.

DGI Indonesia adalah sebuah situs kolaborasi yang memfokuskan diri kepada Sejarah Desain Grafis Indonesia sebagai bagian integral dari warisan kolektif desain grafis internasional. Secara resmi diluncurkan pada 13 Maret 2007, dengan memanfaatkan situs penyedia hosting dan Content Management System gratis bernama WordPress, beralamat di http://desaingrafisindonesia.wordpress.com. Nama DGI pada awalnya dipilih sebagai bentuk kata penyingkat dari Desain Grafis Indonesia, sebuah ranah profesi yang telah digeluti oleh Hanny semenjak puluhan tahun yang lalu. Pada tahun ketiga DGI berkegiatan, tepatnya 13 Maret 2010, diluncurkanlah situs DGI dalam format seperti saat ini beralamat www.DGI-Indonesia.com. Nama DGI Indonesia sendiri dipilih sebagai penyebutan resmi bagi situs tersebut.

Bentuk awal dari kegiatan forum maya ini adalah untuk memupuk saling pengertian di antara desainer grafis Indonesia. Tagline-nya berbunyi: "Fostering understanding among Indonesian graphic designers and its juncture in art, design, culture and society". Konsep saling pengertian di situs ini diwujudkan melalui penerbitan bagian per bagian sejarah desain grafis Indonesia agar angkatan muda mengetahui dan memahami apa yang telah dilakukan oleh angkatan-angkatan pendahulunya. Di dalam perkembangannya DGI-Indonesia.com meluaskan dirinya menjadi pusat informasi, database serta rujukan baik itu untuk akademis maupun profesional di ranah desain grafis. Kini, secara perlahan bukan hanya wilayah keilmuan desain grafis, namun mulai bergerak ke komuniti kreatif Indonesia. Sedang pengembangan area kegiatan diarahkan menuju toko online yang siap menjadi bursa guna menjual serta mendistribusikan hasil publikasi serta barang-barang kreatif. Pengembangan juga dilakukan dengan menyiapkan Online Portfolio di DGI-Indonesia.com sebagai layanan yang menyajikan portfolio visual secara online lewat situs. Sebagai bentuk kontribusi yang bersifat keilmuan, akan disiapkan pusat penelitian dan kajian bagi komuniti Indonesia kreatif dengan mengawalinya pada keilmuan desain grafis. 
Selain itu, sebagai salah satu mimpi dari DGI Indonesia adalah berusaha mewujudkan Penerbit DGI yang akan hadir di tengah keprihatinan pada kondisi belum tersedianya buku-buku desain yang berorientasi pada sejarah desain grafis Indonesia. Terakhir, mimpi besar dari DGI Indonesia adalah memberikan kontribusi penuh bagi pengembangan Museum DGI yang akan menyimpan catatan perjalanan sejarah desain grafis Indonesia. Orientasi pada sejarah menjadi fokus utama DGI Indonesia karena apresiasi yang tinggi atas sejarah akan menjadi sumber inspirasi yang melimpah bagi generasi muda Indonesia.

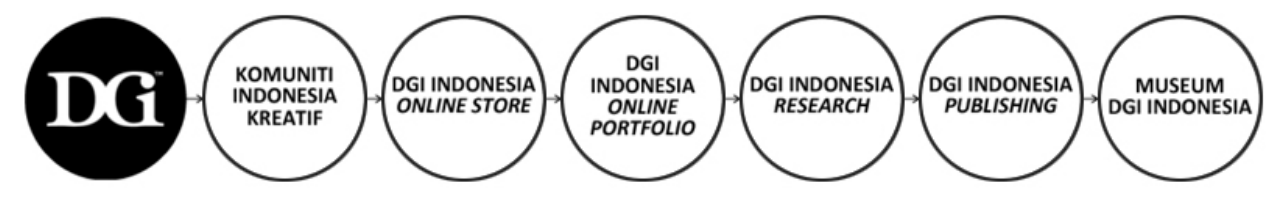

Gambar 1 Arah pengembangan kegiatan DGI Indonesia

\section{Kebutuhan Aktualisasi Diri}

Abraham Maslow memberikan sumbangan penting bagi perkembangan psikologi modern lewat teori aktualisasi-diri (self-actualization). Bicara mengenai aktualisasi-diri tentunya tidak dapat dipisahkan dengan teori Maslow yang membahas persoalan tingkat-tingkat kebutuhan. Maslow mengatakan, kebutuhan-kebutuhan itu adalah faktor-faktor yang mendorong (memotivasi) untuk melakukan perbuatan. Pada tingkat pertama, kebutuhan tersebut berupa kebutuhan fisiologis, adapun kebutuhan yang harus dipenuhi berupa makan, minum dan kebutuhan akan hubungan seksual. Tingkat kedua adalah kebutuhan akan rasa aman (safety needs), pada tingkat kebutuhan ini orang dapat bebas melakukan kegiatannya tanpa terganggu oleh bentuk ancaman yang sekiranya dapat membahayakan keselamatannya. Pada tingkat ketiga, kebutuhan itu berwujud rasa ingin memiliki dan mencinta (social needs), pada tingkatan ini seseorang membutuhkan kelompok sosial tertentu untuk mengikatkan dirinya serta mengidentifikasikan dirinya dengan kelompok tersebut. Kebutuhan akan penghargaan (esteem needs) merupakan tingkatan kebutuhan pada posisi keempat. Terakhir, tingkat kebutuhan kelima dan paling tinggi adalah kebutuhan akan aktualisasi-diri, sebagai bentuk pemanfaatan segala bakat, potensi, serta penggunaan semua kualitas dan kapasitas secara penuh.

Mengutip seperti apa yang dikatakan oleh Maslow, sebagai seorang seniman/desainer, memberdayakan kemampuan kreatif adalah satu upaya untuk memenuhi kebutuhan aktualisasi diri. Langkah yang oleh Abraham Maslow disebut "pemenuhan diri" (self-fulfiliment) menjadi realisasi seluruh potensi dan kebutuhan untuk menjadi insan kreatif (kreator). Kebutuhan tersebutlah yang turut berupaya untuk dipenuhi ruangnya oleh DGI Indonesia. DGI Indonesia berupaya memberikan sebuah ruang yang sanggup memberikan peluang bagi para desainer grafis (pada awalnya) untuk menunjukkan karya-karya mereka, mempresentasikan pemikiran mereka baik lewat visual maupun naratif, berdialog, bertukar pendapat saling mengayakan. Mereka (para desainer grafis) dapat mengikatkan dirinya serta mengidentifikasikan dirinya lewat DGI Indonesia sebagai seorang desainer grafis sebagai bentuk kebutuhan mereka akan wujud rasa ingin memiliki dan mencinta (social needs).

Lewat DGI Indonesia, para desainer/seniman juga dapat memenuhi kebutuhan mereka akan penghargaan (esteem needs), pada saat mereka memamerkan karya-karya mereka secara online maka apresiasi akan mereka dapatkan dari para pengunjung DGI Indonesia.com. Apresiasi yang membangun, kritik dan saran menjadi satu penghargaan tersendiri bagi sang seniman/desainer. Selain itu, dapat memamerkan karya pada komunitinya sendiri pun sudah tentu menjadi satu bentuk pencapaian tersendiri. 
Kesemua kebutuhan tersebut pada akhirnya menemukan muaranya pada bentuk aktualisasidiri. Pengejawantahan atas kebutuhan tersebutlah yang dapat membawa DGI Indonesia pada tingkatan saat ini. Pencapaian jumlah kunjungan 2000-3000 per hari pada hari kerja, sebanyak 1.230 anggota telah mendatakan dirinya di DGI-Indonesia.com serta sejumlah 45.662 friends di jaringan Facebook DGI Indonesia dapat menunjukkan hal tersebut. Pada akhirnya seorang seniman/desainer dapat menciptakan aktualisasi-dirinya lewat karya-karya serta pemikiran yang hebat lewat situs DGIIndonesia.com. DGI Indonesia telah menjawab kebutuhan tersebut.

\section{Membangun Komuniti}

Seperti yang telah dituliskan sebelumnya, DGI Indonesia memiliki 1.230 anggota yang telah mendatakan dirinya lewat situs, serta 45.662 friends di jaringan Facebook DGI Indonesia. Selain itu masih ditambah dengan jaringan data email yang dimiliki guna pemanfaatan newsletter yang secara rutin dikirimkan lewat email, DGI Indonesia telah membentuk komuniti untuk dirinya. Tatanan perilaku bersama terhadap media yang bersangkutan, termasuk bukan hanya bagaimana isi media dikomsumsi (kapan dan di mana isi media tersebut dibaca atau dilihat), tetap juga cara-cara isi media tersebut memengaruhi anggota komunitas tersebut (Genre Tindakan Sosial pada Komunitas Intrepretif -- Lindlof, 1988). Forum online, blog/situs yang berdiri atas komuniti yang berlatar gagasan serta minat yang kuat akan membentuk aturannya sendiri. Aturan-aturan tersebut membentuk prilaku serta tata cara bagaimana anggota tersebut saling berinteraksi dan berkomunikasi. Lewat pendekatan tersebut maka dapat dilihat tata cara yang berkembang di DGI Indonesia.

Situs yang diperuntukkan khususnya bagi komuniti Indonesia kreatif ini telah menjadi media interaksi, bukan hanya saling bertukar informasi, mereka juga dapat memperlihatkan karya yang mereka hasilkan, mengutarakan pemikiran, membagikan pengetahuan. Komentar-komentar saling bersahutan lewat fasilitas yang disediakan, membangun diskusi menarik yang saling mengayakan. Terkadang polemik pun tercipta lewat artikel/tulisan yang saling beradu pemikiran. Kesemuanya itu dapat diperoleh dengan gratis, tanpa dipungut biaya apapun semenjak dari detik pertama mengakses DGI Indonesia. Sejauh ini, kebutuhan dana terutama untuk menjalankan operasional DGIIndonesia.com diambil dari pemasukan iklan serta masih menggunakan dana pribadi yang dikeluarkan oleh Hanny Kardinata.

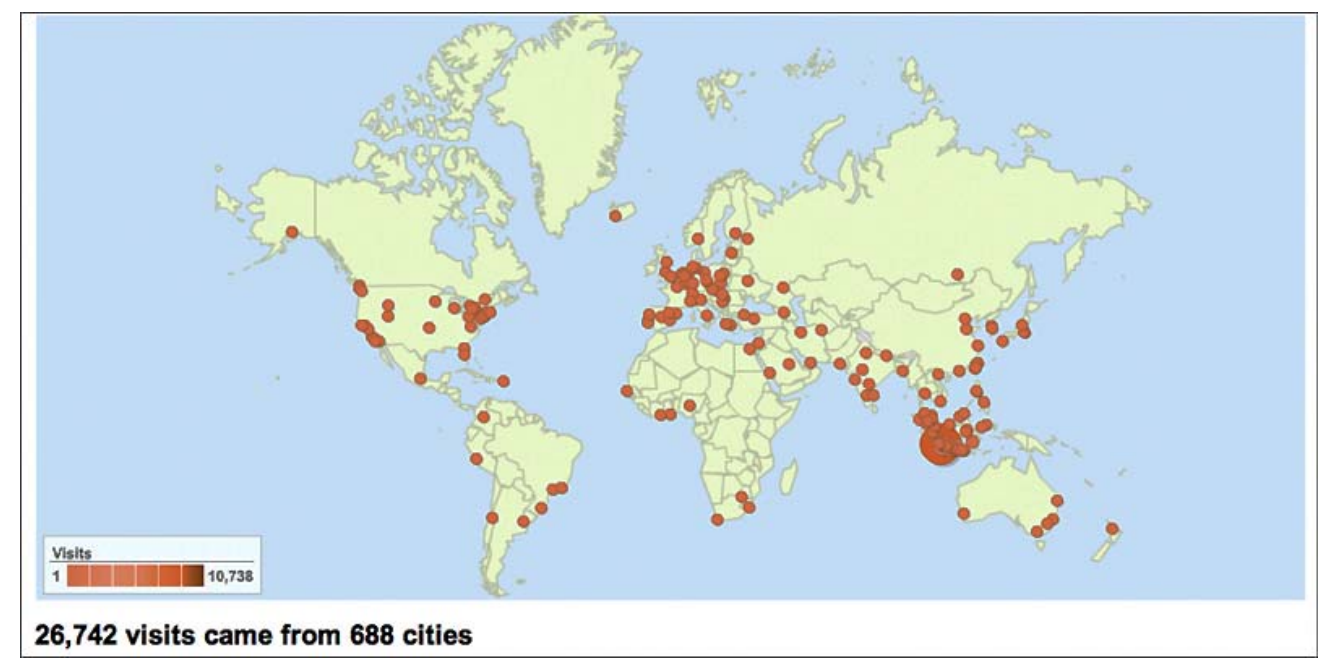

Gambar 2 Peta penyebaran kota-kota asal pengunjung DGI-Indonesia.com. Sumber: Google Analytics, diakses pada 03 Juli 2011 (12.53) 
Bila melihat data pengakses DGI-Indonesia.com lewat Google Analytics, maka akan terlihat pola penyebaran pengunjung yang berasal dari 98 negara di dunia yang datang dari 688 kota. Dari Indonesia sendiri, pengunjung DGI Indonesia berasal dari 33 kota, dengan tetap Jakarta sebagai kota dengan pengunjung terbanyak. Lewat data tersebut dapat dilihat betapa besarnya komuniti yang telah terbentuk oleh DGI Indonesia, dan mereka dapat memanfaatkan data serta informasi yang ada untuk berbagai kebutuhan mereka.

World Wide Web sebagai sebuah lingkungan informasi yang terbuka, fleksibel dan dinamis, yang memungkinkan manusia mengembangkan orientasi pengetahuan yang baru dan juga terlibat dalam dunia demokratis tentang pembagian mutual dan pemberian kuasa yang lebih interaktif dan berdasarkan pada masyarakat. Dunia maya memberikan tempat pertemuan semu yang memperluas dunia sosial, menciptakan peluang pengetahuan baru, dan menyediakan tempat untuk berbagi pandangan secara luas (Cyberculture -- Levy, 1997). DGI Indonesia telah memberikan kesempatan dan peluang yang luas bagi bertukarnya informasi, keilmuan serta pengetahuan menjadi mudah untuk didistribusikan, begitupun dengan opini, komentar dan pendapat. Para pekerja seni dari penjuru tanah air dapat dengan mudah mendapatkan tambahan ilmu dan juga berperan untuk memberikan ilmu bagi orang lain.

Altruisme adalah dasar penting pembentukan dan operasi jejaring sosial. Altruisme dan imbal balik, serta emosi positif seperti cinta dan kebahagiaan, sampai kadar tertentu penting bagi kemunculan dan ketahanan jejaring sosial. (Penyebaran Kebaikan -- Christakis \& Fowler, 2009). Terbentuknya komuniti desain grafis Indonesia tak bisa lepas dari pola altruisme, semangat kebersamaan untuk saling menyebarkan kebaikan. Kebaikan ini berupa ilmu dan pengetahuan seputar seni, desain dan budaya. Anggota komuniti yang terbentuk oleh kesamaan gagasan dan minat tersebut saling melakukan pengayaan lewat interaksi aktif yang berlangsung terus menerus, hingga manfaat yang diperoleh tak lagi menjadi manfaat yang bersifat pribadi di tangan para tim manajemen DGI Indonesia, namun meluas bagi para pengunjungnya, bahkan perkembangan komuniti kreatif yang ada di Indonesia.

\section{Dunia yang Berubah}

Pada buku Sosilogi Komunikasi, Bungin (2007) menekankan pendapat, "Masyarakat maya membangun dirinya dengan sepenuhnya mengandalkan interaksi sosial dan proses sosial dalam kehidupan kelompok (jaringan) intra dan antarsesama anggota masyarakat maya hingga membentuk sebuah jaringan masyarakat yang besar.” Pernyataan tersebut sejalan dengan aktivitas yang kini sedang berjalan di DGI Indonesia, dunia telah berubah, lewat interaksi sosial di dunia maya para pengunjung DGI-Indonesia.com dapat saling berinteraksi, mereka membuat sebuah sistem masyarakat yang saling berdialog mengayakan. Secara perlahan jaringan masyarakat ini kian membesar, seiring dengan interaksi yang semakin meningkat. Kebutuhan akan satu hal di salah satu anggota masyarakat akan cepat direspon oleh anggota masyarakat yang lain. Kehadiran di dunia nyata tak lagi menjadi syarat utama dalam membentuk suatu sistem masyarakat.

Teknologi interaktif dan komunikasi jaringan, khususnya dunia maya akan mengubah masyarakat (Poster, 1990). Mark Poster telah meramalkan semenjak lebih dari dua dekade lalu, bagaimana perkembangan teknologi internet dan komputer akan mengubah susunan masyarakat dan tentunya mengubah cara bagaimana masyarakat tersebut saling berinteraksi. Dunia menjadi semakin sempit, jarak tak lagi menjadi ukuran karena komunikasi dapat berlangsung dengan mudahnya. Setiap keilmuan dan profesi pasti tersentuh oleh perubahan itu, tak terkecuali ranah keilmuan dan profesi yang bersentuhan dengan kreativitas. Para pekerja kreatif turut mengubah gaya dan cara mereka bekerja, merunut pada perkembangan teknologi dan komunikasi yang ada. Saat ini, sebuah pekerjaan kreatif tak harus dilakukan di satu tempat yang sama, salah satu contohnya adalah pengerjaan sebuah komik, bisa saja dimungkinkan, penerbit internasional yang memesan komik tersebut berada di California, Amerika Serikat. 
Pekerjaan cerita dan sketsa dilakukan oleh seorang artis komik di London, Inggris. Proses penintaan dan pewarnaan digital dilakukan oleh sebuah studio yang berada di Bandung, Indonesia. Lalu proses pencetakan dilakukan di China, kemudian disebar ke seluruh dunia setelah mendapat persetujuan dari penerbitan utamanya di California. Kini pekerjaan tak lagi terbatas kepada teritori geografis sebuah negara, namun meluas berasal dari pelosok mancanegara. Tak hanya proses kreatif, perubahan tersebut juga turut meluas hingga cara belajar, cara mendapatkan pekerjaan serta cara berdiskusi. Teknologi informasi yang tertuang ke dalam bentuk tatanan baru dunia maya telah merubah tatanan masyarakat.

Marshall McLuhan turut mengungkapkan hal terkait seputar media memengaruhi masyarakat, terlepas dari fungsi media itu sendiri. Seperti juga diungkapkan oleh Littlejohn \& Foss (2009), memperjelas Teori Media Baru dengan pernyataannya: kita menggunakan media sebagai semacam ritual bersama yang membuat kita merasa sebagai bagian dari sesuatu yang lebih besar dari diri kita. Media diritualkan karena media menjadi kebiasaan, sesuatu yang formal dan memiliki nilai yang lebih besar dari penggunaan media itu sendiri. Kini DGI-Indonesia.com telah menjadi sebuah ritus yang rutin dikunjungi oleh para anggota 'masyarakatnya'. DGI-Indonesia.com tak lagi sekedar menjadi sebuah situs berisi data dan informasi, namun lebih dari itu, telah menjelma menjadi sebuah sistem tatanan masyarakat yang dapat memberikan makna serta dampak positif bagi perkembangan industri serta keilmuan berbasis kreatif di Indonesia.

\section{Manajemen Sumberdaya Budaya Lewat Pemanfaatan Teknologi Informasi Komputer}

Mengutip seperti apa yang dikatakan oleh Sedyawati (2010) mengenai manajemen sumberdaya budaya, beliau mengatakan bahwa "Istilah 'sumberdaya' itu sendiri mengacu kepada suatu penggunaan, atau pemanfaatan tertentu dari sesuatu, untuk pencapaian tujuan yang dapat diukur dari segi 'produktivitas'. Jika kata itu disertai dengan keterangan sifat "budaya”, maka artinya adalah bahwa yang digunakan atau dimanfaatkan itu adalah hal-hal yang bersifat budaya, atau lebih tepatnya hasil-hasil dari suatu kebudayaan. Suatu hasil kebudayaan yang akan dimanfaatkan, atau ditingkatkan daya gunanya, tentulah memerlukan penanganan atau pengelolaan yang tepat, yang seefisien dan seefektif mungkin. “

Manajemen sumberdaya tersebut turut diterapkan dalam pengelolaan data DGI Indonesia. Pemanfaatan teknologi informasi komputer (TIK) turut diterapkan dalam pengelolaan. Data-data serta informasi yang pada awalnya berasal dari kliping Hanny Kardinata secara perlahan dilengkapi oleh semangat komuniti membangun pusat data, para pengunjung turut melengkapi koleksi perjalanan desain grafis Indonesia. Data-data yang didapatkan tersebut lalu disusun berdasarkan kerangka tahun, jenis media serta kerangka kategorisasi hingga memudahkan dalam pencarian. Beberapa data bersifat digital, namun juga terdapat beberapa data bersifat fisik yang disiapkan untuk dikoleksi oleh Museum Desain Grafis Indonesia. Pemanfaatan TIK dengan menggunakan sarana Content Management System berbasis open source, WordPress mencukupi untuk menghasilkan penanganan dokumentasi secara efesien dan efektif.

Menjadi menarik saat mengetahui Direktorat Perguruan Tinggi (Dikti) Kementrian Pendidikan Nasional RI telah menyediakan dana khusus untuk pengembangan TIK ini, dengan mengadakan jenis hibah inherent. Sedang untuk pustaka digital terdapat jenis hibah peningkatan kualitas pendidikan tinggi melalui pengembangan akses pustaka (digital jurnal dan digital references). Tidak hanya itu, Arah Riset Nasional (ARN) yang dikembangkan oleh Kementrian Riset dan Teknologi (2010-2014) pun mendukung pola pemanfaatan TIK dalam mendukung proses database yang bersifat sumber budaya, tema riset yang diangkat Teknologi Digital untuk Industri Kreatif, dengan topik Pengembangan dan pemaketan teknologi kreatif (3D, grafik, animasi) untuk iklan, film, video, fotografi, game, fashion, seni pertunjukan, desain, arsitektur, musik, \& media sebagai sebuah produk 
untuk dipergunakan oleh masyarakat. Melihat kebijakan yang telah dikeluarkan oleh pemerintah maka akan terlihat bahwa DGI Indonesia telah berada di jalur yang tepat, bahkan dapat memanfaatkan dana yang ada untuk pengembangan pusat data digital yang berada di wilayah komuniti Indonesia kreatif.

\section{Peran Sosial sebagai Satu Pilihan, dan Kreativitas akan Menjawab Perubahan}

Tidak diragukan bahwa manusia adalah makhluk yang hanya mementingkan diri sendiri, tetapi mereka juga makhluk yang bisa tidak egois, bisa peduli kepada sesama. Jelaslah manusia juga digerakkan oleh motivasi-motivasi yang tidak mementingkan diri sendiri (Yunus, 2011). Peraih nobel berkebangsaan Bangladesh ini telah membuktikan dirinya bahwa di tiap manusia itu terdapat motivasi-motivasi yang tak lagi hanya berfikir untuk dirinya. DGI Indonesia dapat berjalan semenjak 2007 lewat motivasi ini. Diawali oleh seorang Hanny Kardinata lalu membentuk lingkaran-lingkaran baru dan terus membesar, bukan hanya berasal dari lingkaran manajemen saja, namun kini meluas hingga para anggota/pengunjung situsnya. Keuntungan materi dan finansial tidak menjadi tujuan utama dari berjalannya DGI Indonesia, memberikan manfaat sebesar-besarnya bagi komuniti Indonesia kreatif lah yang menjadi tujuan utama yang disasar. Bila terdapat keuntungan ataupun pemasukan finansial yang didapatkan maka keuntungan tersebut digunakan kembali untuk membiayai operasional DGI Indonesia, selain itu akan diarahkan guna pengembangan komuniti Indonesia kreatif lewat pembiayaan penelitian.

Memperjuangkan profesi dan keilmuan yang kita miliki tentulah menjadi kewajiban dari tiap individu. Keberadaan yang strategis di antara industri-industri lain juga harus diperjuangkan. Kontribusi positif dari pemerintah tentu juga yang selalu dinanti. Lewat aktivitas berbasis sosial dengan menggunakan kendaraan profesi serta keilmuan akan membawa ke tingkat kemanfaatan yang lebih baik, masyarakat akan mendapatkan manfaat yang positif, menaikkan nilai profesi dan keilmuan yang kita miliki, kuatnya komuniti akan berdampak kepada iklim usaha serta proses kaderisasi di ranah akademis akan semakin menuju titik ideal. Hal ini sejalan dengan apa yang dikatakan oleh Yunus (2011), "Bisnis-bisnis sosial memberi setiap orang kesempatan untuk berperan serta dalam menciptakan macam dunia yang ingin kita lihat. Berkat konsep bisnis sosial, masyarakat tidak harus menyerahkan semua masalah ke tangan pemerintah (dan selanjutnya menghabiskan umur mereka untuk mencela pemerintah karena gagal memecahkan masalah-masalah)” (p. xxx).

Bila menengok ke hal paling mendasar dari manfaat yang dapat diperoleh dari peran keilmuan serta profesi di wilayah kreatif (terutama desain), maka kita dapat mengacu kepada apa yang dikatakan oleh Walker (2010). Ia mengatakan, "Walaupun semua desain berlangsung dalam masyarakat, tampaknya penting untuk mempertahankan satu pembedaan antara desain yang bermanfaat secara sosial dan desain yang mengganggu secara sosial (karena itu 'antisosial' atau 'desain antimanusia') meskipun, tentunya, orang berbeda pendapat tentang apa yang bermanfaat dan apa yang merusak. Ketika kata 'sosial' terjadi di dalam wacana desain dan sejarah desain, selalu dipakai dalam pengertian bermanfaat secara sosial.” Bermanfaat secara sosial di sini tentunya dapat diartikan secara luas. Bermanfaat sosial bagi komunitinya sendiri atau bermanfaat sosial bagi masyarakat luas, tak ada yang salah dengan keduanya. Memberikan manfaat sosial bagi komunitinya pada akhirnya dapat memberikan manfaat juga kepada masyarakat. Begitupun dengan yang dilakukan oleh DGI Indonesia, lewat situs berbasis komuniti ini, manfaat sosial dapat diperoleh dan terus menciptakan pusaran positif mashlahatan kehidupan manusia.

Seorang desainer branding dapat memberikan kontribusinya lewat komprehensif branding yang terwujud nyata dalam visual identitas yang sangat kuat, mengirimkan pesan, menyampaikan gagasan, mengkomunikasikan sebuah keberadaan dan peran. Lalu bersama komuniti yang telah teridentitaskan tersebut kembali menyebarkan pesan tersebut menjadi lebih meluas. Pilihan untuk bersama berjuang dengan memberikan kontribusi keahlian serta kompetensi yang tak beda dengan 
pada saat kerja profesional menjadikan hasil yang didapat menjadi sangat berkualitas. Hal itu yang dilakukan oleh desainer branding yang telah merancang identitas visual DGI Indonesia.

Begitupun dengan seorang desainer web, peran sosial pun dapat diambil dalam beraktivitas. Terlebih era dunia maya tengah berlangsung dengan hiruk pikuknya, pilihan untuk memberikan kontribusi tentu menjadi pilihan yang akan memberikan manfaat. Segala potensi yang dimiliki oleh teknologi informasi berbasis web, termasuk juga jejaring sosial, dapat dimanfaatkan dalam mengelola pesan/komunikasi yang ingin diperjuangkan. Selain itu, manfaat dalam pengelolaan datapun menjadi wilayah yang sangat membutuhkan pengelolaan yang serius. Terlebih di masa depan, yang menjadi konsentrasi tak lagi di seberapa banyak data yang kita miliki, namun bergeser kepada seberapa tepat dan cepat kita mendapatkan data yang paling sesuai dengan yang kita butuhkan, dan peran seorang desainer web menjadi sangat besar di sana.

Sedang bagi seorang pekerja kreatif, misalnya desainer grafis, dapat mengutip apa yang dikatakan oleh Hanny Kardinata, "Penerapan idealisme di desain grafis dalam arti yang paling mendasar, desain grafis adalah masalah bagaimana memberikan solusi secara kreatif terhadap suatu masalah, dan apabila Anda selalu memberikan solusi yang terbaik maka itu adalah sesuatu yang ideal. Ini mungkin idealisme dalam arti yang sederhana. Tapi prinsip ini bisa diperluas ke hal-hal yang lebih bersifat pengabdian, yaitu ketika Anda bekerja tidak saja sebagai desainer grafis aktif tetapi juga sebagai aktivis desain grafis, dan berkarya nyata bagi kepentingan komuniti.” Terdapat penekanan pada kata idealisme, pengabdian dan aktivis desain grafis. Tiga komponen tersebut menjadi kekuatan mendasar yang dapat menciptakan perubahan. Terlebih kekuatan desain grafis yang sebenarnya adalah mencari solusi-solusi kreatif dari permasalahan apapun yang ditemui. Perubahan yang terjadi pada dunia, bergesernya pola kerja serta aktivitas dalam memanfaatkan teknologi media baru menjadi tantangan yang dapat dijawab oleh para pekerja kreatif. Idealisme akan senantiasa dibutuhkan demi menciptakan desain ataupun karya yang bukan 'antisosial' ataupun 'antimanusia', dengan selalu berorientasi kepada kepentingan sosial, kepentingan yang lebih luas, kepentingan yang dapat membuat kehidupan menjadi lebih baik lagi, tak melulu kepada keinginan menciptakan keuntungan finasial semata.

\section{PENUTUP}

Perubahan telah terjadi di banyak sektor kehidupan manusia. Perubahan yang terjadi itu merupakan sebuah hukum alam serta setiap saat menimbulkan masalah baru. (Bungin, 2007). Dibutuhkan peran dari berbagai pihak untuk merespon perubahan tersebut, bukan hanya untuk menjawab persoalan yang turut hadir. Kebutuhan baru atas ruang maya guna aktualisasi diri dapat terjawab dengan tersedianya ruang maya berbasis komuniti yang saling memberikan pencerahan ilmu serta pengetahuan. Aktualisasi diri dapat diperoleh dari peran saling memberikan ilmu pengetahuan. Dunia yang berubah berupa dunia maya yang mampu memberikan ruang baru eksplorasi yang begitu luas, termasuk interaksi. Komuniti berbasis dunia maya menjadi jawaban bagi semakin berkembangnya suatu ilmu dan profesi, segenap kemudahan yang diberikan menjadi titik awal yang dapat menentukan berkembangnya ilmu dan profesi itu sendiri. Diskusi, interaksi, data serta informasi yang terkumpulkan menjadi sumber data yang sangat penting untuk dimanfaatkan, untuk itulah peran manajemen sumber daya budaya dapat mengambil peran, terlebih apabila teknologi informasi dan komputer telah turut mengambil bagian, maka segenap kemudahan dan manfaat akan mudah kita dapatkan. Lalu terakhir, tinggal pilihan kita untuk melipatgandakan manfaat-manfaat tersebut dengan memilih pendekatan peran sosial, melalui aktivitas bisnis sosial, juga pendekatan-pendekatan kreatif untuk menjawab permasalahan, serta keinginan untuk bekerja sesuai idealisme yang sarat dengan pengabdian. Hingga kehidupan manusia yang lebih baik akan memperoleh jawabannya. 


\section{DAFTAR PUSTAKA}

Bungin, B. (2007). Sosilogi komunikasi. Jakarta: Kencana.

Christakis, N. A., \& Fowler, J. H. (2010). CONNECTED: Dahsyatnya kekuatan jejaring sosial mengubah hidup kita. (Z. Anshor, terj.). Jakarta: Gramedia Pustaka Utama.

Levy, P. (1997). Cyberculture. Paris: Odile Jacob.

Littlejohn, S. W., \& Foss, K. A. (2009). Teori komunikasi. Jakarta: Salemba Humanika.

Goble, F. G. (1994). Mazhab ketiga psikologi humanistik Abraham Maslow. (A. Supratiknya, terj.). Yogyakarta: Kanisius.

Sedyawati, E. (2010). Budaya Indonesia: Kajian arkeologi, seni, dan sejarah. Jakarta: Rajawali Press.

Sign Magazine. (2009). Idealisme: Menggali sudut pandang 'idealisme' seorang Hanny Kardinata. Sign Magazine, No. 2, Februari 2009.

Walker, J. A. (2010). Desain, sejarah, budaya: Sebuah pengantar komprehensif. (L. Rahmawati, terj.). Yogyakarta: Jalasutra.

Yunus, M. (2011). Bisnis sosial: Sistem kapitalisme baru yang memihak kaum miskin. (A. T. Kantjoro, terj.). Jakarta: Gramedia.

\section{RIWAYAT PENULIS}

Danu Widhyatmoko lahir di kota Tangerang pada 24 Juni 1977. Penulis menamatkan pendidikan S1 di Universitas Trisakti dalam bidang ilmu Desain Komunikasi Visual pada tahun 2000. Saat ini sedang mengambil studi pascasarjana di IKJ Jakarta, Seni Urban dan Industri Budaya. Bekerja sebagai Faculty Member - Jurusan Desain Komunikasi Visual, Fakultas Komunikasi dan Multimedia, BINUS University. Penulis aktif di DGI Indonesia (www.DGI-Indonesia.com) sebagai Research and Development (RnD) Director dan Kepak Garuda (www.KepakGaruda.com) sebagai pemilik dan pengelola. 